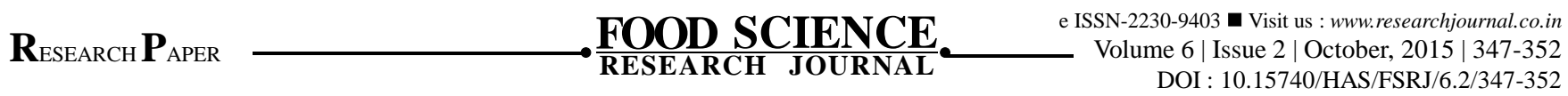

\title{
Physico-chemical characteristics of paddy, milled and parboiled rice varieties
}

\author{
Madhuri Kotagi, N. Surekha, Ravikumar S. Naik and N.B. Yenagi
}

\begin{abstract}
An investigation was planned to study the physico-chemical characteristics of paddy, milled and parboiled rice varieties. There was a significant difference in physical characteristics among 15 paddy, milled and parboiled rice varieties. The mean length $(6.85 \mathrm{~mm})$, breadth $(2.49 \mathrm{~mm})$ and L:B ratio $(2.17)$ of parboiled rice was greater as compared to milled rice. The analysis of chemical characteristics of 15 rice varieties revealed that rice variety Dodiga $(84.04 \%)$ had higher starch content, followed by Udarsali (82.10\%), Amurth (78.57\%), Abhilash (78.10\%) and the lowest in Avinash (73.45\%). There was a significant variation in total amylose content of paddy varieties with a range of 25.43 to 32.30 per cent. Soluble and insoluble amylose content of paddy varieties ranged from 12.41 to 20.12 per cent and 11.26 to 16.37 per cent, respectively. The amylopectin content of paddy varieties varied significantly $(\mathrm{P}<0.01)$ and ranged from 67.73 to 74.57 per cent. The highest amylopectin content was observed in Prasanna (74.57\%), Intan (72.39\%), Champakali (71.77\%) and the lowest in Avinash (67.73\%). There was a strong relationship between physico-chemical characteristics and processing qualities of rice viz., popping, puffing and flaking.
\end{abstract}

Key Words : Paddy, Milled rice, Parboiled rice, L : B ratio, Amylase, Amylopectin

How to cite this article : Kotagi, Madhuri, Surekha, N., Naik, Ravikumar S. and Yenagi, N.B. (2015). Physico-chemical characteristics of paddy, milled and parboiled rice varieties. Food Sci. Res. J., 6(2): 347-352.

Author for correspondence :

N. SUREKHA, Department of Food and Nutrition, Rural Home Science College, University of Agricultural Sciences, DHARWAD (KARNATAKA) INDIA

Associate Authors' :

MADHURI KOTAGI AND N.B. YENAGI, Department of Food and Nutrition, Rural Home Science College, University of Agricultural Sciences, DHARWAD (KARNATAKA) INDIA

Email : madhuri-kotagi@yahoo.com

RAVIKUMAR S. NAIK, Department of Agricultural Economics, University of Agricultural Sciences, DHARWAD (KARNATAKA) INDIA

Email : ravinaik-cci@rediffmail.com 